OPEN ACCESS

Edited by:

Natasa Skalko-Basnet,

Arctic University of Norway, Norway

Reviewed by:

Sybil Obuobi,

UiT the Arctic University of Norway, Norway

Godwin W. Nchinda,

CIRCB, Cameroon

*Correspondence:

Raj Kumar Thapa r.k.thapa@farmasi.uio.no

Specialty section:

This article was submitted to

Pharmaceutical Innovation,

a section of the journal

Frontiers in Medical Technology

Received: 25 March 2021

Accepted: 01 June 2021

Published: 24 June 2021

Citation:

Thapa RK, Grønlien KG and

Tønnesen HH (2021) Protein-Based

Systems for Topical Antibacterial

Therapy.

Front. Med. Technol. 3:685686

doi: 10.3389/fmedt.2021.685686

\section{Protein-Based Systems for Topical Antibacterial Therapy}

\author{
Raj Kumar Thapa*, Krister Gjestvang Grønlien and Hanne Hjorth Tønnesen \\ Section for Pharmaceutics and Social Pharmacy, Department of Pharmacy, University of Oslo, Oslo, Norway
}

Recently, proteins are gaining attention as potential materials for antibacterial therapy. Proteins possess beneficial properties such as biocompatibility, biodegradability, low immunogenic response, ability to control drug release, and can act as protein-mimics in wound healing. Different plant- and animal-derived proteins can be developed into formulations (films, hydrogels, scaffolds, mats) for topical antibacterial therapy. The application areas for topical antibacterial therapy can be wide including bacterial infections in the skin (e.g., acne, wounds), eyelids, mouth, lips, etc. One of the major challenges of the healthcare system is chronic wound infections. Conventional treatment strategies for topical antibacterial therapy of infected wounds are inadequate, and the development of newer and optimized formulations is warranted. Therefore, this review focuses on recent advances in protein-based systems for topical antibacterial therapy in infected wounds. The opportunities and challenges of such protein-based systems along with their future prospects are discussed.

Keywords: antibacterial therapy, chronic infected wounds, proteins, topical formulations, wound healing

\section{INTRODUCTION}

The integrity and function of the skin as a physical permeation barrier are crucial for protecting against the external environment, including particles, exogenous chemicals, and microorganisms (1). The skin is considered the largest human organ and is composed of two main layers; epidermis and dermis (2). The epidermis is further divided into five separate layers (in order from most superficial to deepest: stratum corneum, stratum lucidum, stratum granulosum, stratum spinosum, and stratum basale) (3). The barrier function and transportation of compounds into the skin can be attributed to the most superficial layer, stratum corneum, and is governed by a brick-like structure of corneocytes (4). The second skin layer is the dermis, which is responsible for the strength and elasticity of the skin. The dermis consists mainly of fibroblast cells and fibrous proteins, such as collagen and elastin (5). The skin has a microbiota composed of numerous bacteria and fungi with an essential role in the protection against invading pathogens (6). A breach of the skin barrier can disturb the balance between commensals and pathogens, resulting in skin disease and infection (7).

The barrier function of the skin can be reduced by trauma, such as accidental injury, cuts, scrapes and burns, or skin disease. Disruption of the skin can lead to impaired protection against the external environment, including the risk of infections and compromised immunity (8). Diseased skin, such as common acne and atopic dermatitis is associated with dysbiosis between common commensal species, resulting in inflammation and epidermal barrier impairment (6). Changes in the skin microbiota can also be the result of diseases, such as immunodeficiency diseases and diabetes $(9,10)$. 
Wounds that do not heal by an orderly sequence of events and within a predictable amount of time are defined as chronic (11). The pathophysiology of chronic wounds is characterized by a disturbance in the normal physiological conditions, including the colonization of opportunistic pathogens (Figure 1). Bacterial infections may cause wound deterioration, which will slow down the healing process and prevent wound closure $(13,14)$. Opportunistic pathogens, such as the Gram-positive bacterium $S$. aureus and the Gram-negative bacterium $P$. aeruginosa are prevalent in chronic wounds $(13,14)$ which can form biofilms characterized by an aggregation of immobilized bacterial cells in an adhesive extracellular matrix $(15,16)$. Biofilm formation affects the wound healing process by delaying epithelialization and granulation tissue formation. Such wounds express lower levels of inflammatory markers, thus disturbing the mechanisms of recovery (17). Further, the production of destructive enzymes and toxins may promote a chronic inflammatory state of the wound and prevent the healing process (18).

Topical drug delivery can be used for delivery of drugs through the skin, i.e., transdermal drug delivery, or formulations

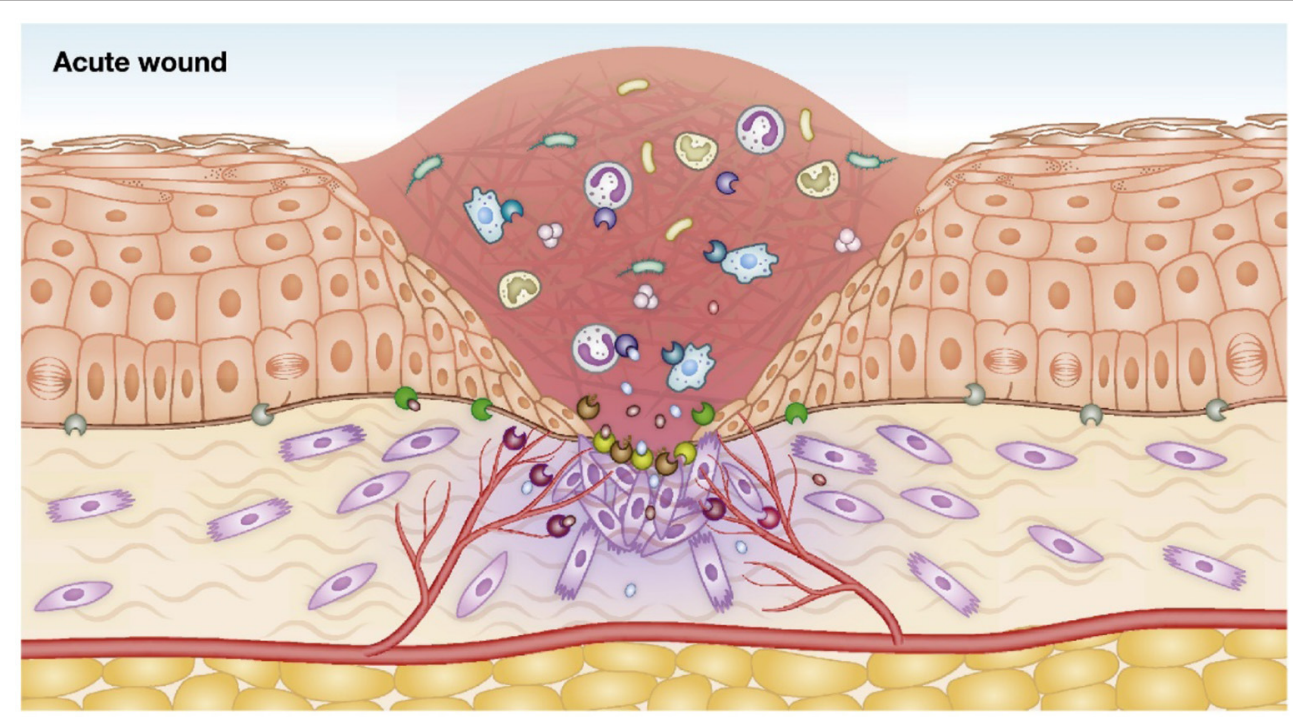

Chronic wound

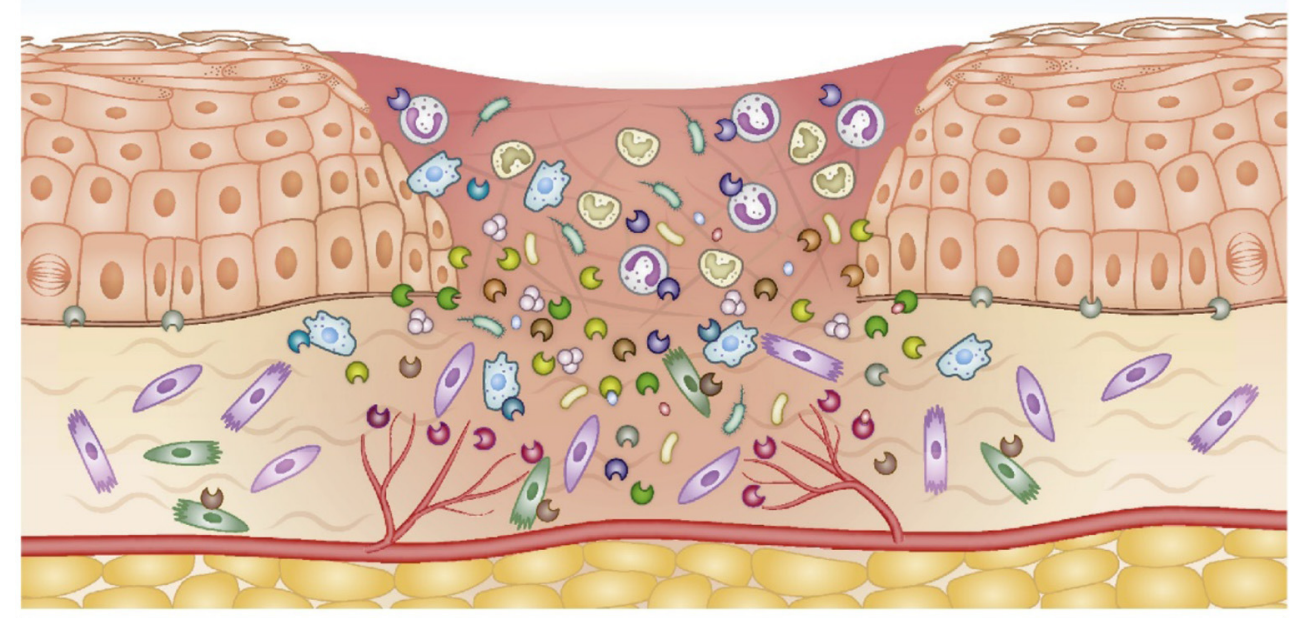
Q MMP-1
ค MMP-9
G3 Macrophage
P.aeruginosa
Timp-1
(4) MMP-2
(2) MMP- 10
(4) Neutrophil
E.coli
Timp-2
(C) ${ }_{M M P-3}$
( ${ }_{\text {MMP-12 }}$
(C) Monocyte
- Fibroblast
(4) MMP-8
( $M M P-13$
8) S.aureus
1. Distinct stromal cell

FIGURE 1 | Schematic of the differences between acute and chronic wounds illustrated by an increased imbalance between proteolytic enzymes and their inhibitors, and invasion of opportunistic bacteria leading to delayed wound healing in chronic wounds. Adapted with permission from Krishnaswamy et al. (12). 
may be applied for local action, i.e., retention of the active ingredient on the skin surface or within the epidermal layers without systemic absorption (19). Topical antibiotics and antiseptics are commonly prescribed to treat superficial bacterial infections $(20,21)$. However, clinical guidelines have been focused on systemically or intravenously administered antibiotics (20). The clinical usage of topical antibacterial treatment has been limited to superficial skin infections, such as impetigo, chronic wounds and burns, and the prevention of postsurgical wound infections and minor traumatic wound infections (20). Conventional antibacterial agents used for topical treatment include antiseptics, such as chlorhexidine, triclosan, and hydrogen peroxide, and antibiotics such as mupirocin, bacitracin, polymixin B, neomycin, gentamicin, silver sulfadiazine, and fusidic acid (20,22). A major concern regarding the use of antibiotics includes the potential resistance development by the infecting bacteria (23). Thus, an optimal formulation is required to effectively kill the pathogens and lower the risk of resistance development. Commercial formulations for topical antibacterial therapy have been based on conventional formulation techniques, such as emulsions (creams and lotions), ointments, and hydrogels, and moisture-retentive dressings, such as hydrocolloids and poly-urethane foams (20, 22, 24). The major advantages of topical formulations are their local effects without systemic absorption leading to fewer side effects, ease of application, moisturizing properties, low cost of production, and inexpensiveness for patients (25). However, the topical application may interfere with the wound healing process and the normal microbiota. Further, the residence time of the active ingredient may be too short for a proper effect, and the dose accuracy may be low. Some patients may find the application of the formulations painful $(22,25)$. Thus, there is a need for modified formulations suitable for topical applications.

\section{PROTEINS: ROLES IN WOUND HEALING AND TOPICAL ANTIMICROBIAL THERAPY}

Wound healing is a complex biological process involving damaged tissue replacement with a living one (26). The tissue integrity is restored as a result of interactions of platelets, cells (e.g., monocytes/macrophages, neutrophils, fibroblasts, keratinocytes, and endothelial cells), and extracellular matrix (ECM) components $(27,28)$. The ECM not only provides essential physical scaffolding for the cellular constituents but also initiates crucial biochemical and biomechanical cues that are required for tissue morphogenesis, differentiation, and homeostasis (29). The ECM is composed of two main classes of macromolecules: proteoglycans and fibrous proteins (30). Collagen, elastin, fibronectin, and laminin are the main fibrous proteins in the ECM (31). Collagen is the most abundant fibrous protein within the interstitial ECM (constitutes up to $30 \%$ of total protein mass) with important functions including regulation of cell adhesion, provide tensile strength, support chemotaxis and migration, and directs tissue development for wound healing (32). Collagen further associates with elastin fibers that provide recoil to tissues undergoing repeated stretch (33). Fibronectin protein is involved in directing the organization of interstitial ECM and has a crucial role in mediating cell attachment and function (34).

Some proteins and peptides have inherent antimicrobial properties. Such antimicrobial proteins and peptides have been studied for their potential in the treatment of bacterial wound infections in addition to their wound healing properties (35). Antimicrobial peptides (AMPs) are the host-defense peptides produced by animals, plants, fungi, bacteria, and protozoa. Detailed information on potent AMPs for topical application in wounds is available elsewhere (36). Several AMPs (e.g., Pexiganan, Omiganan, Lytixar, Dalbavancin, and Brilacidin) with potential as antibacterial agents are in different phases of clinical trials for future commercial developments (37). Additionally, there are some enzymes (e.g., lysozyme, phospholipase $\mathrm{A}_{2}$ ) that possess antibacterial properties. These proteinaceous molecules have a different mechanism of actions e.g., lysozyme breaks the bond between the N-acetylglucosamine (NAG) and $\mathrm{N}$ acetylmuramic acid (NAM) which make up the peptidoglycan backbone (38), and phospholipase $\mathrm{A}_{2}$ penetrate the bacterial cell wall and hydrolyzes the phospholipids in the bacterial cytoplasmic membrane (39).

Besides the inherent antimicrobial properties of proteins and peptides, they can be used in the preparation of formulations for the treatment of topical infections in wounds. Different plant- and animal-derived proteins have been studied for their potential in wound healing. Protein wound dressings, such as hydrogels, sponges, and sheets have advantages in wound healing by adhering to the tissue and absorbing excess wound exudate. Protein formulations may further protect the wound against secondary infections and retain a moist wound healing environment (40-42). Such protein formulations are prepared by different methods including desolvation, nanoprecipitation, coacervation, emulsification, self-assembly, layer-by-layer assembly, and electrospinning (43). Among these methods, electrospinning has gained recent interest in the preparation of protein-based systems for topical drug delivery. The electrospinning process generates ultrathin fibers by utilizing electrostatic force to the protein or polymeric solution (44), and these fibers can be used for the modification and control of drug release (45).

\section{PROTEINS AND THEIR FORMULATIONS FOR TOPICAL ANTIBACTERIAL THERAPY OF INFECTED WOUNDS}

Proteins such as collagen, silk fibroin, zein, albumin, and casein can be used as a carrier (e.g., hydrogels, films, wafers, and electrospun fibers, and mats) for antimicrobial agents to support antimicrobial action and promote healing of infected wounds (Figure 2).

The protein-based systems loaded with antimicrobial agents and investigated for their antibacterial activity are summarized below: 


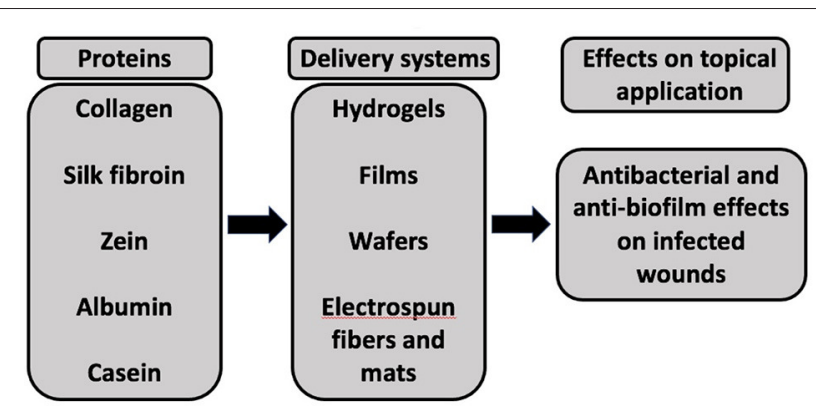

FIGURE 2 | A schematic representation of different proteins used as delivery systems for antimicrobial agents to exhibit antibacterial and anti-biofilm effects upon application to infected wounds.

\section{Collagen}

Collagen is the main component of connective tissue composed of a triple helix formed by three $\alpha$-chains (repeating triplets of the amino acids glycine-X-Y where $\mathrm{X}$ and $\mathrm{Y}$ are often proline and the imino acid hydroxyproline, respectively) (46). It has been isolated from bovine, porcine, equine, avian, and aquatic species (47-49). Collagen derived from aquatic sources (fish and jellyfish) and plant-derived recombinant collagen has further been investigated as potential alternatives to mammalian collagen to mitigate issues on transmissible diseases and religious preferences (4951). Additionally, collagen from marine sources has also gained attention because of the AMPs derived from their collagen. An example of such AMP is collagencin which is derived from fish collagen (52). The exogenous collagen is biocompatible, biodegradable, non-toxic, and weakly antigenic compared to other natural polymers (53). Collagen can cross-link and selfaggregate to form fibers with high tensile strength and stability (46). These fibers can be formulated into different scaffolds for wound dressing. Collagen has an ability to attract proteases, which have been exploited in commercial products acting as sacrificial substrates, protecting the endogenous collagen in the wound bed $(54,55)$. Gelatin is a hydrolyzed form of collagen which can also be utilized for topical application in infected wounds (56). Collagen is a highly versatile material with potential applications for burn/wound cover dressings (57). Recently, the drug delivery properties of collagen have been widely studied. Collagen-based drug delivery systems for potential topical application in infected wounds include microspheres based on gelatin, collagen scaffolds, collagen hydrogels, collagen/collagensynthetic polymer hydrogels, and collagen films. Most of the commercial formulations of collagen are available only as skin substitutes for wound healing application but do not possess antibacterial activity (58). There are only two commercial collagen-based antimicrobial dressings containing silver as an antimicrobial agent: collagen/oxidized regenerated cellulose (ORC)-silver (Promogran ${ }^{\circledR}$ Prisma, Systagenix) and collagensilver (Puracol ${ }^{\circledR}$ Plus Ag+, Medline) (59). However, collagen dressings containing other antimicrobial agents are still lacking in the commercial market. Different studies exploring the potential of collagen-based systems as topical antibacterial agents have been published. The examples of such collagen-based systems for topical antibacterial therapy of infected wounds are presented in Table 1. The combination of wound healing and controlled drug release properties of collagen can effectively kill the infecting bacteria and assist in the wound healing process. However, a potential disadvantage is the protease-mediated growth of $S$. aureus under nutrient-limited conditions while using collagen in an antibacterial system (68). Therefore, rigorous in vitro and in vivo studies are required to optimize and establish the potential use of collagen-based systems as topical antibacterial therapy for infected wounds.

\section{Silk Fibroin}

Silk fibroin is a biologically-derived protein polymer purified from domesticated silkworm (Bombyx mori) or non-mulberry (Antheraea assama) cocoons (69) with unique properties including biocompatibility (70), biodegradability (71), mechanical strength (72), high water and oxygen uptake (73), and excellent properties for drug delivery and tissue engineering (74). The regulation of beta sheet content (crystallinity) can control the degradation time course of silk implants from days to years $(75,76)$. Furthermore, the incorporation of sensitive compounds (e.g., proteins) without loss of bioactivity is possible in silk attributable to its ability to be processed in aqueous systems under mild and ambient conditions of temperature and pressure $(77,78)$. There are reports on the use of silk fibroin as an antibacterial biomedical nanotextile for wound dressing (79) and as a controlled release system for antibiotics (80). However, there are no commercial antibacterial products based on silk fibroin. Several studies exploring the topical antibacterial potential of silk fibroin-based systems have been published. The examples of such systems for topical antibacterial therapy of infected wounds are presented in Table 2. Rigorous studies are warranted to establish the in vivo antibacterial potential of topical silk fibroin-based systems for commercial development in the treatment of infected wounds.

\section{Zein}

Zein is a plant protein found in maize endosperm (84) composed of nonpolar and uncharged amino acids glutamine, leucine, proline, and alanine (85). The solubility of zein is determined by its amino acid composition and are accordingly classified as $\alpha, \beta, \gamma$, and $\delta$ zein (86). Zein is a biocompatible and biodegradable polymer with potential applications in biomedical and pharmaceutical fields (87). It is widely used in the food and pharmaceutical industry attributable to its ability to form a tough, glossy coating with antibacterial activity $(84,88)$. Zein can be prepared as nanoparticles, microspheres, films, fibers, and composites with other natural polymers (87) using the evaporation-induced self-assemblage mechanism for controlled delivery of drugs (89). So far, there are no commercial products of zein for topical antibacterial therapy of infected wounds. Published literature suggest the potential of zein-based systems as potent topical antibacterial formulations. Examples of such systems are presented in Table 3. 
TABLE 1 | Collagen-based systems for topical antibacterial therapy of infected wounds.

\begin{tabular}{|c|c|c|c|c|c|c|c|}
\hline $\begin{array}{l}\text { Collagen-based } \\
\text { formulation }\end{array}$ & Active ingredient & Preparation method & $\begin{array}{l}\text { Additional } \\
\text { polymer/ } \\
\text { nanoparticle }\end{array}$ & $\begin{array}{l}\text { Treatment } \\
\text { purpose }\end{array}$ & $\begin{array}{l}\text { Target } \\
\text { microorganism }\end{array}$ & Outcomes & References \\
\hline Film & Pexiganan & $\begin{array}{l}\text { Simple mixing of active ingredient and } \\
\text { collagen, and air drying }\end{array}$ & - & $\begin{array}{l}\text { Infected rat wound } \\
\text { model (in vivo) }\end{array}$ & $\begin{array}{l}\text { S. aureus and } P \text {. } \\
\text { aeruginosa }\end{array}$ & $\begin{array}{l}\text { The sustained pexiganan release was observed } \\
\text { for } 72 \mathrm{~h} \text {; in vivo wound bacteria inhibition was } \\
3-5 \text { fold higher compared to open wound or } \\
\text { blank collagen film }\end{array}$ & (60) \\
\hline Scaffold & Silver sulfadiazine & $\begin{array}{l}\text { Simple mixing of silver sulfadiazine } \\
\text { loaded alginate microspheres in } \\
\text { pepsin-solubilized collagen }\end{array}$ & $\begin{array}{l}\text { Alginate } \\
\text { microspheres }\end{array}$ & $\begin{array}{l}\text { In vitro } \\
\text { antibacterial } \\
\text { studies }\end{array}$ & $\begin{array}{l}\text { K. Pneumoniae, E. } \\
\text { coli, P. aeruginosa, } \\
\text { and } S \text {. aureus }\end{array}$ & $\begin{array}{l}\text { The collagen scaffold controlled drug release } \\
\text { for up to } 72 \mathrm{~h} \text {. Minimum inhibitory } \\
\text { concentrations (MIC) and minimum bactericidal } \\
\text { concentration (MBC) were K. Pneumoniae } \\
\text { (MIC: } 32 \mu \mathrm{g} / \mathrm{mL} \text { and MBC: } 40.2 \mu \mathrm{g} / \mathrm{mL} \text { ), E. coli } \\
\text { (MIC: } 32 \mu \mathrm{g} / \mathrm{mL} \text { and MBC: } 40.2 \mu \mathrm{g} / \mathrm{mL} \text { ), P. } \\
\text { aeruginosa (MIC: } 44.8 \mu \mathrm{g} / \mathrm{mL} \text { and MBC: } \\
51.2 \mu \mathrm{g} / \mathrm{mL} \text { ), S. aureus (MIC: } 57.6 \mu \mathrm{g} / \mathrm{mL} \text { and } \\
\text { MBC: } 57.6 \mu \mathrm{gL} \text { ) }\end{array}$ & (61) \\
\hline Scaffold & Doxycycline & $\begin{array}{l}\text { Simple mixing of doxycycline loaded } \\
\text { gelatin microspheres in } \\
\text { pepsin-solubilized collagen }\end{array}$ & $\begin{array}{l}\text { Gelatin } \\
\text { microspheres }\end{array}$ & $\begin{array}{l}\text { Infected rat wound } \\
\text { model (in vivo) }\end{array}$ & $P$. aeruginosa & $\begin{array}{l}\text { Early subsidence of infection (99.9\%) by day } 9 \\
\text { for collagen scaffold treated infected wounds } \\
\text { whereas, for the control group, the microbial } \\
\text { load exceeded } 10^{3} \mathrm{CFU} \text { even on day } 15\end{array}$ & (62) \\
\hline Hydrogel & Lysostaphin & $\begin{array}{l}\text { Mixing of solubilized chitosan and } \\
\text { collagen, and subsequently } \\
\text { incorporating lysostaphin into the } \\
\text { purified hydrogels }\end{array}$ & Chitosan & $\begin{array}{l}\text { Infected rabbit } \\
\text { burn wound model } \\
\text { (in vivo) }\end{array}$ & $\begin{array}{l}\text { Methicillin resistant } \\
\text { S. aureus (MRSA) }\end{array}$ & $\begin{array}{l}\text { The MIC of chitosan-collagen hydrogel } \\
\text { incorporating lysostaphin (CCHL) was } 0.053 \\
\mathrm{U} / \mathrm{mL} \text {. No bacteria were detected in the } \\
\text { wounds by the second week of } \mathrm{CCHL} \\
\text { application on MRSA infected third-degree } \\
\text { burn wounds. }\end{array}$ & (63) \\
\hline Wafers & Gentamicin & $\begin{array}{l}\text { Electrospinning of } \\
\text { polycaprolactone/collagen nanofibers } \\
\text { and subsequent coating with micelles } \\
\text { composed of polypeptide-based } \\
\text { block copolymer }\end{array}$ & $\begin{array}{l}\text { Polycaprolac- } \\
\text { tone/polypeptide } \\
\text { based block } \\
\text { copolymer micelle }\end{array}$ & $\begin{array}{l}\text { In vitro } \\
\text { antibacterial } \\
\text { studies }\end{array}$ & S. aureus & $\begin{array}{l}\text { The gentamicin-loaded wafers were able to kill } \\
>99.99 \% \text { of S. aureus }\end{array}$ & (64) \\
\hline Nano-composite & $\begin{array}{l}\text { Gentamicin sulfate } \\
\text { and sodium } \\
\text { rifamycin }\end{array}$ & $\begin{array}{l}\text { Resuspending drug loaded silica } \\
\text { particles in collagen gel }\end{array}$ & Silica particles & $\begin{array}{l}\text { Infected rat wound } \\
\text { model (in vivo) }\end{array}$ & S. aureus & $\begin{array}{l}\text { Sustained antibacterial effects over } 10 \text { days in } \\
\text { vitro and } 2 \text { log reduction in the bacterial } \\
\text { population following treatment with } \\
\text { nanocomposites }\end{array}$ & (65) \\
\hline Scaffold & $\begin{array}{l}\text { Silymarin and } \\
\text { silver nitrate }\end{array}$ & $\begin{array}{l}\text { Mixing of chitosan and collagen along } \\
\text { with silymarin, and addition of bi-layer } \\
\text { scaffolds of silver incorporated } \\
\text { chitosan and collagen }\end{array}$ & Chitosan & $\begin{array}{l}\text { No in vitro or in } \\
\text { vivo antibacterial } \\
\text { studies were } \\
\text { performed }\end{array}$ & - & $\begin{array}{l}\text { Antibacterial studies are warranted for further } \\
\text { assessment of in vitro and in vivo antibacterial } \\
\text { activity of the scaffold }\end{array}$ & (66) \\
\hline Scaffold & $\begin{array}{l}\text { Zinc oxide } \\
\text { nanoparticles }\end{array}$ & $\begin{array}{l}\text { Homogenized mixing of zinc oxide } \\
\text { nanoparticles in collagen gel }\end{array}$ & $\begin{array}{l}\text { Zinc oxide } \\
\text { nanoparticles }\end{array}$ & $\begin{array}{l}\text { In vitro } \\
\text { antibacterial } \\
\text { studies }\end{array}$ & $\begin{array}{l}\text { S. aureus and } E \text {. } \\
\text { coli }\end{array}$ & $\begin{array}{l}\text { Growth inhibition zones of the scaffold were } \\
\text { comparable to those obtained for tested } \\
\text { antibiotics (methicillin, trospectomycin, and } \\
\text { ceftolozane/tazobactam for S. aureus; and } \\
\text { colistin, streptomycin, and rifampin for E. coli. }\end{array}$ & (67) \\
\hline
\end{tabular}


TABLE 2 | Silk fibroin-based systems for topical antibacterial therapy of infected wounds.

\begin{tabular}{|c|c|c|c|c|c|c|c|}
\hline $\begin{array}{l}\text { Silk } \\
\text { fibroin-based } \\
\text { formulation }\end{array}$ & Active ingredient & Preparation method & $\begin{array}{l}\text { Additional } \\
\text { polymer/ } \\
\text { nanoparticle }\end{array}$ & $\begin{array}{l}\text { Treatment } \\
\text { purpose }\end{array}$ & $\begin{array}{l}\text { Target } \\
\text { microorganism }\end{array}$ & Outcomes & References \\
\hline Hydrogel & Ampicillin & $\begin{array}{l}\text { Prepared from an aqueous solution of silk } \\
\text { fibroin protein polymer and bulk loaded } \\
\text { ampicillin }\end{array}$ & - & $\begin{array}{l}\text { Infected mouse } \\
\text { wound model (in } \\
\text { vivo) }\end{array}$ & S. aureus & $\begin{array}{l}\text { Sustained ampicillin release was observed } \\
\text { for } 72 \mathrm{~h} \text {; in vivo wound bacteria inhibition } \\
\text { was } 20 \text { fold higher compared to untreated } \\
\text { wound }\end{array}$ & (80) \\
\hline Electrospun mats & $\begin{array}{l}\text { Polyethylene-imine } \\
\text { (PEI) }\end{array}$ & $\begin{array}{l}\text { PEl and silk fibroin were dissolved in } \\
\text { formic acid to achieve a final concentration } \\
\text { of } 15 \% \mathrm{w} / \mathrm{v}\end{array}$ & PEI & $\begin{array}{l}\text { In vitro } \\
\text { antibacterial } \\
\text { studies }\end{array}$ & $\begin{array}{l}\text { S. aureus and } P \text {. } \\
\text { aeruginosa }\end{array}$ & $\begin{array}{l}\text { Potent antibacterial activity against both } \\
\text { bacteria and their complete inhibition }\end{array}$ & (79) \\
\hline Film & $\begin{array}{l}\text { Ciprofloxacin } \\
\text { Amoxicillin } \\
\text { Nystatin }\end{array}$ & $\begin{array}{l}\text { Simple mixing of antibiotics to } 8 \% \mathrm{~W} / \mathrm{v} \text { silk } \\
\text { fibroin solution prior to casting }\end{array}$ & - & $\begin{array}{l}\text { In vitro } \\
\text { antibacterial } \\
\text { studies }\end{array}$ & $\begin{array}{l}\text { S. aureus, } P \text {. } \\
\text { aeruginosa, } K \text {. } \\
\text { pneumonia, } A \text {. } \\
\text { baumannii, E. coli, } \\
\text { and } C \text {. tropicalis }\end{array}$ & $\begin{array}{l}\text { The antibacterial activity of free drug } \\
\text { solutions was maintained by the } \\
\text { mucoadhesive silk fibroin films }\end{array}$ & (81) \\
\hline Composite film & Gold nanoparticles & $\begin{array}{l}\text { Simple mixing of silk fibroin solution and } \\
\text { gold nanoparticles prior to casting }\end{array}$ & Gold nanoparticle & $\begin{array}{l}\text { Infected rat wound } \\
\text { model (in vivo) }\end{array}$ & $\begin{array}{l}\text { Multidrug resistant } \\
\text { E. coli }\end{array}$ & $\begin{array}{l}\text { Complete inhibition of multidrug resistant } \\
\text { bacteria in vitro and efficiently combat } \\
\text { infection in in vivo wound model }\end{array}$ & (82) \\
\hline $\begin{array}{l}\text { Layer-by-layer } \\
\text { deposited } \\
\text { nanofibers }\end{array}$ & Lysozyme & $\begin{array}{l}\text { Composite nanofibrous mats were } \\
\text { prepared from mixed solutions of silk } \\
\text { fibroin and nylon } 6 \text { using electrospinning. } \\
\text { Lysozyme and collagen were alternately } \\
\text { assembled on the prepared mats by } \\
\text { layer-by-layer deposition. }\end{array}$ & $\begin{array}{l}\text { Lysozyme and } \\
\text { collagen alternate } \\
\text { deposition of } 10 \\
\text { layers on silk } \\
\text { fibroin and nylon } 6 \\
\text { composite } \\
\text { nanofibrous mat }\end{array}$ & $\begin{array}{l}\text { In vitro } \\
\text { antibacterial } \\
\text { studies }\end{array}$ & $\begin{array}{l}\text { E. coli, and } S \text {. } \\
\text { aureus }\end{array}$ & $\begin{array}{l}>80 \% \text { and }>98 \% \text { reduction in the viable } \\
\text { count of } E \text {. coli, and S. aureus }\end{array}$ & (83) \\
\hline
\end{tabular}




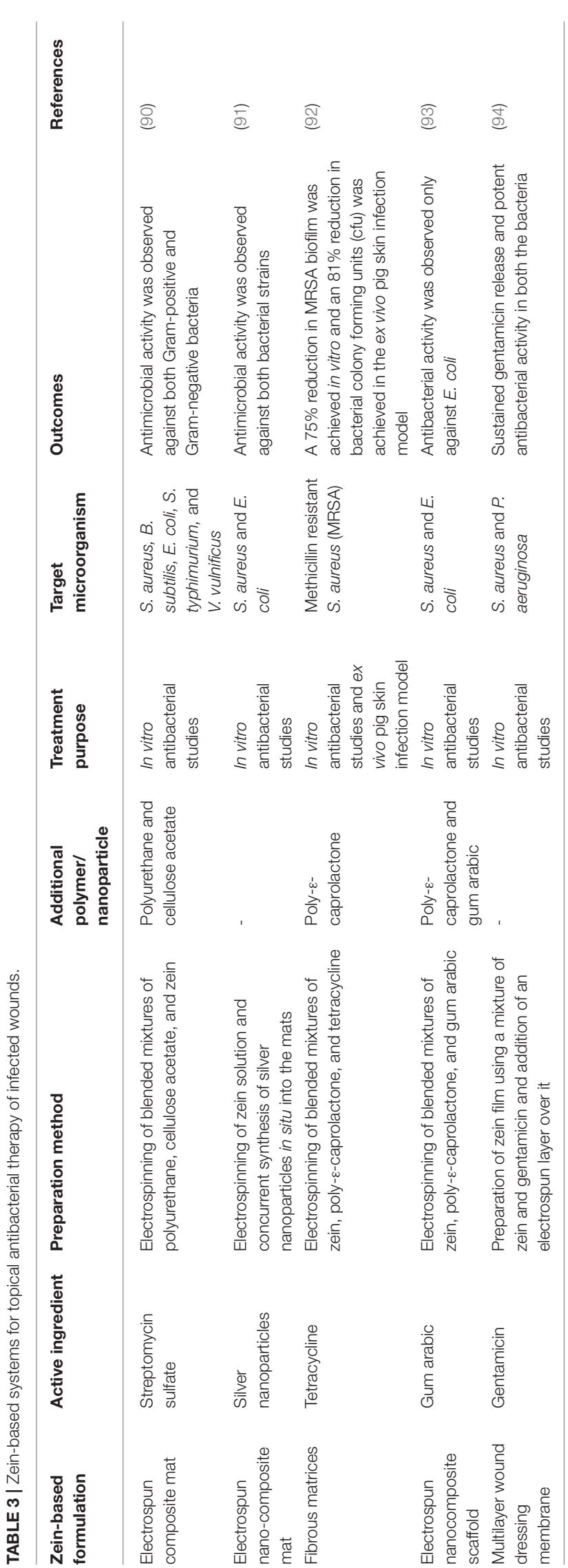

\section{Albumin}

Albumin is the most abundant plasma protein (35-50 g/L human serum) with a molecular weight of $66.5 \mathrm{kDa}$ (95). It is produced by the liver and has an important role in maintaining the osmotic pressure of plasma and transporting endogenous compounds (proteins, cholesterol, and bile pigments) (96). Albumins (bovine serum albumin and human serum albumin) are widely utilized for a variety of clinical and biomedical research applications attributable to their advantageous intrinsic properties such as biocompatibility, biodegradability, low immunogenicity, and non-toxicity $(95,97)$. Albumin possesses non-specific protein adsorption property that has led to its design as an antimicrobial material to reduce the adhesion of pathogenic bacteria $(98,99)$. Coating of a polystyrene membrane with human serum albumin inhibited biofilm formation by E. coli (100) and pneumococcal strains (101). Nevertheless, the inhibitory effect of albumin is still limited to certain bacterial species (102) and can even stimulate bacterial growth in other species $(100,101)$. Such inhibitory effect of albumin can be utilized in the preparation of topical films or patches with albumin coatings to promote anti-biofilm activity once applied to susceptible wounds. The triggered release behavior of albumin nanoparticles (103) can be potentially utilized for the on-demand antibacterial release upon application to infected wounds. Furthermore, albumin coatings on nanoparticles can facilitate the targeting and trafficking during drug delivery (104). Similar strategies can be used for topical application of albumin coated nanoparticles to facilitate uptake inside the cells infected with bacteria for the induction of antibacterial effects. There are limited literature about the use of albumin-based systems for topical antibacterial therapy. Further research in this field is warranted to explore the potential use of albumin-based systems for the topical antibacterial therapy.

\section{Casein}

Casein is a milk phosphoprotein that constitutes a major $(\approx 80 \%)$ proportion of cow milk protein content $(105)$. It is a proline-rich, amphiphilic protein, which can self-assemble into micellar structures (106). Casein is inexpensive, non-toxic, and heat-stable, and can form film attributable to its random coil conformation (107). Although there are reports on different formulations of casein [nanoparticles (108), microparticles (109), micelles (110), films (111), hydrogels (112)] in drug and enzymatic delivery; there are negligible studies about casein-based antimicrobial preparations for topical applications. The high availability, biocompatibility, and biodegradability properties of casein make it a suitable protein for the potential delivery of bioactive molecules and antimicrobial agents for topical delivery in tissue engineering and wound healing. The film formation of casein is attributable to polar amino acid groups $(\approx 55 \%)$ responsible for the hydrogen bond formations but this property leads to poor electrospinnability arising from low viscoelasticity in solution (113). Addition of suitable synthetic polymers such as polyethylene oxide (113) and polyvinyl alcohol (114) can solve the electrospinning problem. There is a single study on the casein-based topical antimicrobial preparation performed by Selvaraj et al. based on electrospinning of casein nanofibers with silver nanoparticles (113). In this study, the 
blended mixture of casein, polyethylene oxide, and silver nanoparticles was electrospun to prepare nanofibrous mats that were crosslinked with glutaraldehyde vapor. The incorporation of silver nanoparticles led to the potent antimicrobial activity against S. aureus, E. coli, and B. subtilis. Further casein-based topical antimicrobial formulations need to be developed to assess their potential in the treatment of topical infections, especially in chronic wounds.

\section{PROTEIN-BASED DELIVERY SYSTEMS FOR ANTIBACTERIAL THERAPY}

Based on the available literature, as presented above, different delivery systems (hydrogels, films, wafers, and electrospun fibers and mats) have been prepared for the antibacterial therapy. An overview of these delivery systems is presented below:

\section{Hydrogels}

Hydrogels are three-dimensional polymeric networks capable of absorbing large amounts of water or biological fluids (up to 1,000 times their dry weight). Their insolubility is attributed to the presence of cross-links between the constituents that form the polymeric network $(115,116)$. Hydrogels have several advantages including biocompatibility, tunable biodegradability, mechanical strength, and porous structure suitable for topical applications (117). Proteins can be suitable building blocks for hydrogels since they are biocompatible and easily degraded by the body (118). More importantly, different chemical reactions including click chemistry, UV-initiated cross-linking, Michael addition of cysteine residues to vinyl sulfones or maleimides, and native chemical reactions can be performed with proteins to form hydrogels (119). Collagen is widely used as a biomaterial in its native fibrillar form as well as after denaturation to form hydrogel (120). The factors influencing self-assembly of collagen to hydrogel include temperature, ionic conditions, $\mathrm{pH}$, and cross-linking agent (121). Silk fibroin forms $\beta$-sheets due to the presence of the highly repetitive amino acid motif GAGAGS. These sheets are responsible for silk fibroin's insolubility in water. The hydrophobic interactions among the protein chains in fibroin result in the assembly of the material into hydrogels. Gelation can be enhanced by an increase in temperature or fibroin concentration, a decrease in $\mathrm{pH}$ or by addition of a hydrophilic polymer. Furthermore, addition of $\mathrm{Ca}^{2+}$ ions also accelerates the formation of hydrophobic interactions with the $\mathrm{COO}^{-}$ions of the amino acid side chains (122). Different antimicrobials can be incorporated into these protein hydrogels for inducing the antibacterial effects on infected wounds.

\section{Films}

Film dressings are adhesive, durable, comfortable, transparent, and cost-effective materials used for covering the wounds and providing antibacterial effects. Films can be made up of different materials including proteins. Protein films are one of the most widely synthesized protein-based materials. Different strategies are employed in generating protein films which include: natural self-assembly of proteins (123), cross-linking of proteins via physical or chemical approaches (124), and thermal treatment for initiation of the reorganization of proteins $(125,126)$. Furthermore, post-functionalization of the surface or incorporation of additives can impart new characteristics or enhance native properties of the film (127). Structural proteins with highly repetitive amino acid sequences such as silk and collagen naturally self-assemble into water-stable protein films using different processing methods like casting or printing $(123,128)$. Silk fibroin films possess properties including biocompatibility, slow degradation, and robust mechanical properties $(129,130)$. Silk fibroin self-assembles into $\beta$ sheets resulting in water-stable films. Mechanical strength and biodegradability of silk fibroin films can be enhanced by controlling $\beta$-sheet percentage using different strategies such as methanol annealing, water annealing, and drying speed (131, 132). Collagen consists of three parallel polypeptide- $\alpha$ chains in a right-handed triple helical structure that self-associates to form highly ordered cross-linked fibrils (133) resulting in collagen film insolubility in water. Collagen is usually purified and can be dissolved in acid solutions to form films (134) or alternatively, collagen fibers are directly used to prepare films (135).

\section{Wafers}

Wafers are prepared as freeze-dried or electrospun forms of proteins consisting of porous structures (136). Collagen can be used to form wafers in freeze-dried form, which can absorb fluid upon application to the wound surface and change their state from a dehydrated porous solid to a viscous gel permitting the diffusion of antimicrobial agent to the wounds (137, 138). Silk fibroin porous wafers can be prepared using porogens, freezedrying, gas forming, and electrospun fibers (139) for application to the wounds.

\section{Electrospun Fibers and Mats}

Electrospinning is a process of applying a high voltage to a polymer solution for transforming a drop at the needle tip into a cone shape in order to generate a jet (140). The ejected jet undergoes a number of instabilities, during which the solvent from the solution is evaporated and dry fibers are collected on the grounded or oppositely charged plates (141). The diameter size, distribution, and morphology of electrospun fibers can be adjusted and tuned according to the solution (e.g., molecular weight, concentration, viscosity, surface tension, conductivity, and dielectric constant) and process parameters (e.g., temperature, flow rate, humidity, working distance, and voltage) (142). Proteins are widely used for the preparation of electrospun wound dressings alone or in combination with other natural and/or synthetic polymers. Zein is extensively utilized in the preparation of electrospun fibers and mats for antimicrobial delivery to infected wounds. A major advantage of electrospinning zein is the avoidance of toxic solvents and cross-linkers due to its solubility in aqueous ethanol and selfassembling nature $(143,144)$. However, aqueous ethanol is not an ideal solvent for electrospinning (145) because of its high evaporation rate that leads to needle clogging, formation of ribbon-shaped fibers and results in poor water solubility of the fibers $(146,147)$. This problem can be overcome by coaxial electrospinning with ethanol (146) or polyethylene oxide 
(PEO) as a shell solution (148) or by cross-linking zein with UV radiation (149). Casein has recently gained attention as a starting material for electrospinning. It's $55 \%$ is constituted of polar amino groups which allow the formation of hydrogen bonds. This property leads to poor electrospinnability of casein which is further compromised due to its low viscoelasticity in solution $(113,150,151)$. Therefore, electrospinning is only possible upon addition of synthetic polymers such as polyethylene oxide (PEO) (113) and polyvinyl alcohol (PVA) (114). Furthermore, the high hydrophilicity of casein leads to weak mechanical strength and water stability, which requires the use of toxic crosslinking agents such as silane and glutaraldehyde $(113,114)$. Silk fibroin protein has a low weight $\left(1.3 \mathrm{~g} \mathrm{~cm}^{-3}\right)$ and high tensile strength $(\sim 4.8 \mathrm{GPa})$ which makes it ideal for the production of electrospun fibers (152). The mechanical properties of silk fibroin fibers can be altered through methanol treatment after electrospinning, which increases $\beta$-sheet crystallinity and reduces water solubility (153). In case of collagen protein, care needs to be taken during electrospinning because denaturation may occur at high voltage (154). Collagen is often co-electrospun with other synthetic polymers such as polycaprolactone (PCL) to increase fiber stability (155).

\section{OPPORTUNITIES AND CHALLENGES OF PROTEIN-BASED SYSTEMS FOR TOPICAL ANTIBACTERIAL THERAPY}

Proteins possess a number of benefits for topical application in the treatment of infected wounds. The biocompatibility of proteins makes them suitable as a topical formulation for antibacterial therapy (156). Furthermore, the biodegradability of proteins, irrespective of their origin (plant or animal), is possible via physiological mechanisms (157). For example, collagen is naturally degraded in chronic wounds by matrix metalloproteinases (158) and zein is degraded by enzymatic, microbial, or cell phagocytosis pathways (159). Proteins such as collagen, gelatin, and elastin possess cell-recognition motifs like RGD (Arginine-Glycine-Aspartate) that can facilitate recognition by cells to promote cell adhesion and cell migration across the wound bed for promotion of wound healing (160) in addition to their antimicrobial potential. Other proteins such as lactoferrin (161) and lysozyme (38) possess innate antimicrobial, anti-inflammatory, and anti-oxidant activity to facilitate antibacterial and wound healing effects. A great diversity of antimicrobial agents (antibiotics, antimicrobial nanoparticles, antimicrobial peptides, antimicrobial polymers), as mentioned above, can be integrated into protein-based systems to elicit antimicrobial responses against Gram-positive and Gram-negative bacteria.

Besides several benefits, there are still some challenges in the use of protein-based systems for topical antibacterial therapy. The treatment of biofilms on infected wounds is still challenging. Protein based systems can control or sustain the release of antibacterial agent, however, penetration into the biofilm is still limited (162). Therefore, suitable modifications in the proteinbased systems (e.g., inclusion of biofilm disassembly agents like nuclease and extracellular protease within the protein formulation) could enhance the antibacterial activity of the system (163). The lack of regulations to ensure structural homogeneity and purity of protein-based materials has led to variations in their quality (164). The purity, composition, and activity of proteins are affected by the diversity in extraction and purification methods that can influence the formulation characteristics. The preparation methods for topical formulations require the use of different solvents (water or organic solvents) with proteins that can affect protein stability and activity (165). Sterilization of the proteins is another challenge (166). Conventional sterilization techniques based on high temperature or gamma radiation have limitations, such as protein denaturation and changes in the amino acid structure (166-168). Proteins can be susceptible to UV radiation as well (169). Viable alternative sterilization methods that can preserve protein structure and properties include supercritical $\mathrm{CO}_{2}$, acid treatment (with peracetic acid), and the use of gas plasma (166, 170-172). Most common protein-based systems for topical antibacterial therapy include films, hydrogels, and electrospun matrices. The preparation of films and hydrogels requires a simple blend of proteins with antimicrobial agents and thus does not have a greater impact on the stability and activity of proteins $(81,173)$. However, the electrospinning of proteins requires the use of different components including cross-linking agents, organic solvents, and a high voltage that can potentially damage protein structure and subsequent loss of its activity (174). Electrospinning of hydrophilic proteins like silk fibroin and casein is also challenging due to its surface tension in water leading to non-continuous processes and artifacts in fibers in addition to their aggregation and low degree of protein unfolding in water (175). Furthermore, for proteins with amphiphilic nature such as zein, the final product loses its fibrous structure and becomes more elastic upon contact with water (148). Therefore, choice of protein and suitable modifications in the formulation methods are necessary to maintain protein's functions and stability as a potent protein-based antibacterial system. So far, there are few reports on the use of different protein-based systems for topical antibacterial therapy. Wide varieties of proteins (plant- and animal-based) besides mentioned in this review are available. However, studies on their use for topical antibacterial therapy are still lacking. Therefore, extensive research on such proteins is warranted to explore their potential as topical antibacterial formulations.

\section{CONCLUSIONS AND FUTURE PROSPECTS}

Protein-based systems are emerging as potential formulations for topical delivery of antimicrobial agents. The beneficial properties of proteins including biocompatibility, biodegradability, and low immunogenic response make them suitable carriers for different antimicrobial agents. The preparation method of topical formulations (films, hydrogels, and mats) requires different treatment conditions that can affect protein stability and activity. 
Hence, proper optimization of the preparation method to ensure stability and activity of proteins along with potent antimicrobial delivery is required. Protein-based systems are capable of controlling the release of active ingredients once applied topically to the infected wound and can act as wound protein mimics to support the wound healing process. Furthermore, the ability of proteins to absorb wound exudates and prevent secondary infections makes them suitable candidates for topical application as an antibacterial system for infected wounds. However, treatment of the biofilms is still challenging attributable to limited penetration of the antibacterial agents. Therefore, suitable modifications in the protein-based formulations for enhancing the antibacterial efficacy is warranted. There are several in vitro studies performed for the evaluation of the antibacterial activity of protein-based topical antibacterial formulation, however, in

\section{REFERENCES}

1. Elias PM. Skin barrier function. Curr Allergy Asthma Rep. (2008) 8:299305. doi: 10.1007/s11882-008-0048-0

2. Thulabandu V, Chen D, Atit RP. Dermal fibroblast in cutaneous development and healing. Wiley Interdiscip Rev Dev Biol. (2018) 7:e307. doi: $10.1002 /$ wdev.307

3. Fuchs E. Skin stem cells: rising to the surface. J Cell Biol. (2008) 180:27384. doi: $10.1083 /$ jcb. 200708185

4. Menon GK, Cleary GW, Lane ME. The structure and function of the stratum corneum. Int J Pharm. (2012) 435:3-9. doi: 10.1016/j.ijpharm.2012.06.005

5. Nam GH, Kawk HW, Kim SY, Kim YM. Solvent fractions of fermented Trapa japonica fruit extract stimulate collagen synthesis through TGF- $\beta 1 / G S K-$ $3 \beta / \beta$-catenin pathway in human dermal fibroblasts. $J$ Cosmet Dermatol. (2020) 19:226-33. doi: 10.1111/jocd.13253

6. Byrd AL, Belkaid Y, Segre JA. The human skin microbiome. Nat Rev Microbiol. (2018) 16:143-55. doi: 10.1038/nrmicro.2017.157

7. Grice EA, Segre JA. The skin microbiome. Nat Rev Microbiol. (2011) 9:24453. doi: 10.1038/nrmicro2537

8. Proksch E, Brandner JM, Jensen J-M. The skin: an indispensable barrier. Exp Dermatol. (2008) 17:1063-72. doi: 10.1111/j.1600-0625.2008.00786.x

9. Thimmappaiah Jagadeesh A, Prakash PY, Karthik Rao N, Ramya V. Culture characterization of the skin microbiome in Type 2 diabetes mellitus: a focus on the role of innate immunity. Diabetes Res Clin Pract. (2017) 134:17. doi: 10.1016/j.diabres.2017.09.007

10. Catinean A, Neag MA, Mitre AO, Bocsan CI, Buzoianu AD. Microbiota and immune-mediated skin diseases-An overview. Microorganisms. (2019) 7:279. PubMed PMID: doi: 10.3390/microorganisms7090279

11. Frykberg RG, Banks J. Challenges in the treatment of chronic wounds. $A d v$ Wound Care. (2015) 4:560-82. doi: 10.1089/wound.2015.0635

12. Krishnaswamy VR, Mintz D, Sagi I. Matrix metalloproteinases: the sculptors of chronic cutaneous wounds. Biochim Biophys Acta. (2017) 1864(11, Part B):2220-7. doi: 10.1016/j.bbamcr.2017.08.003

13. Serra R, Grande R, Butrico L, Rossi A, Settimio UF, Caroleo B, et al. Chronic wound infections: the role of Pseudomonas aeruginosa and Staphylococcus aureus. Exp Rev Anti-infect Therap. (2015) 13:60513. doi: 10.1586/14787210.2015.1023291

14. Roy S, Santra S, Das A, Dixith S, Sinha M, Ghatak S, et al. Staphylococcus aureus biofilm infection compromises wound healing by causing deficiencies in granulation tissue collagen. Ann Surg. (2020) 271:1174-85. doi: 10.1097/SLA.0000000000003053

15. Wu Y-K, Cheng N-C, Cheng C-M. Biofilms in chronic wounds: pathogenesis and diagnosis. Trends Biotechnol. (2019) 37:505-17. doi: 10.1016/j.tibtech.2018.10.011

16. Mancl KA, Kirsner RS, Ajdic D. Wound biofilms: lessons learned from oral biofilms. Wound Repair Regenerat. (2013) 21:352-62. doi: 10.1111/wrr. 12034 vivo studies are still lacking. More in vivo studies of such potent formulations are required in the future to support the clinical translation of the prepared protein-based systems as topical anti-bacterials.

\section{AUTHOR CONTRIBUTIONS}

All authors listed have made a substantial, direct and intellectual contribution to the work, and approved it for publication.

\section{FUNDING}

This study was supported by the Research Program on Better Health and Quality of Life (BEDREHELSE) from the Research Council of Norway (\# 273646).

17. Metcalf DG, Bowler PG. Biofilm delays wound healing: a review of the evidence. Burns Trauma. (2013) 1:3329. doi: 10.4103/2321-3868.113329

18. Percival SL, McCarty SM, Lipsky B. Biofilms and wounds: an overview of the evidence. Adv Wound Care. (2014) 4:373-81. doi: 10.1089/wound.2014.0557

19. Benson HAE, Grice JE, Mohammed Y, Namjoshi S, Roberts MS. Topical and transdermal drug delivery: from simple potions to smart technologies. Curr Drug Deliv. (2019) 16:444-60. doi: 10.2174/1567201816666190201143457

20. Williamson DA, Carter GP, Howden BP. Current and emerging topical antibacterials and antiseptics: agents, action, and resistance patterns. Clin Microbiol Rev. (2017) 30:827. doi: 10.1128/CMR.00112-16

21. Cardona AF, Wilson SE. Skin and soft-tissue infections: a critical review and the role of telavancin in their treatment. Clin Infect Dis. (2015) 61 Suppl 2:S69-78. doi: 10.1093/cid/civ528

22. Lipsky BA, Hoey C. Topical antimicrobial therapy for treating chronic wounds. Clin Infect Dis. (2009) 49:1541-9. doi: 10.1086/644732

23. Ventola CL. The antibiotic resistance crisis: part 1: causes and threats. $P T$. (2015) 40:277-83.

24. Bowler PG. Wound pathophysiology, infection and therapeutic options. Ann Med. (2002) 34:419-27. doi: 10.1080/078538902321012360

25. Mayba JN, Gooderham MJ. A guide to topical vehicle formulations. $J$ Cutaneous Med Surg. (2017) 22:207-12. doi: 10.1177/1203475417743234

26. Thapa RK, Margolis DJ, Kiick KL, Sullivan MO. Enhanced wound healing via collagen-turnover-driven transfer of PDGF-BB gene in a murine wound model. ACS Appl Bio Mater. (2020) 3:3500-17. doi: 10.1021/acsabm.9b01147

27. Raghow R. The role of extracellular matrix in postinflammatory wound healing and fibrosis. FASEB J. (1994) 8:82331. doi: 10.1096/fasebj.8.11.8070631

28. Midwood KS, Williams LV, Schwarzbauer JE. Tissue repair and the dynamics of the extracellular matrix. Int J Biochem Cell Biol. (2004) 36:10317. doi: 10.1016/j.biocel.2003.12.003

29. Bonnans C, Chou J, Werb Z. Remodelling the extracellular matrix in development and disease. Nat Rev Mol Cell Biol. (2014) 15:786801. doi: 10.1038/nrm3904

30. Järveläinen H, Sainio A, Koulu M, Wight TN, Penttinen R. Extracellular matrix molecules: potential targets in pharmacotherapy. Pharmacol Rev. (2009) 61:198. doi: 10.1124/pr.109.001289

31. McKee TJ, Perlman G, Morris M, Komarova SV. Extracellular matrix composition of connective tissues: a systematic review and meta-analysis. Sci Rep. (2019) 9:10542. doi: 10.1038/s41598-019-46896-0

32. Rozario T, DeSimone DW. The extracellular matrix in development and morphogenesis: a dynamic view. Dev Biol. (2010) 341:12640. doi: 10.1016/j.ydbio.2009.10.026

33. Wise SG, Weiss AS. Tropoelastin. Int J Biochem Cell Biol. (2009) 41:4947. doi: 10.1016/j.biocel.2008.03.017

34. Singh P, Carraher C, Schwarzbauer JE. Assembly of fibronectin extracellular matrix. Annu Rev Cell Dev Biol. (2010) 26:397419. doi: 10.1146/annurev-cellbio-100109-104020 
35. Coutinho HDM, Lôbo KM, Bezerra DAC, Lôbo I. Peptides and proteins with antimicrobial activity. Indian J Pharmacol. (2008) 40:39. doi: 10.4103/0253-7613.40481

36. Thapa RK, Diep DB, Tønnesen HH. Topical antimicrobial peptide formulations for wound healing: current developments and future prospects. Acta Biomaterialia. (2020) 103:52-67. doi: 10.1016/j.actbio.2019.12.025

37. Wang J, Dou X, Song J, Lyu Y, Zhu X, Xu L, et al. Antimicrobial peptides: promising alternatives in the post feeding antibiotic era. Med Res Rev. (2019) 39:831-59. doi: 10.1002/med.21542

38. Zhou D, Yang T, Qian W, Xing M, Luo G. Study of the mechanism of environmentally friendly translucent balsa-modified lysozyme dressing for facilitating wound healing. Int J Nanomed. (2018) 13:4171-87. doi: 10.2147/IJN.S165075

39. Buckland AG, Wilton DC. The antibacterial properties of secreted phospholipases A(2). Biochim Biophys Acta. (2000) 1488:71-82. doi: 10.1016/s1388-1981(00)00111-6

40. Sood A, Granick MS, Tomaselli NL. Wound dressings and comparative effectiveness data. Adv Wound Care. (2013) 3:511-29. doi: 10.1089/wound.2012.0401

41. Sai K P, Babu M. Collagen based dressings - a review. Burns. (2000) 26:54-62. doi: 10.1016/S0305-4179(99)00103-5

42. Xiang J, Shen L, Hong Y. Status and future scope of hydrogels in wound healing: synthesis, materials and evaluation. Eur Polymer J. (2020) 130:109609. doi: 10.1016/j.eurpolymj.2020.109609

43. Varanko A, Saha S, Chilkoti A. Recent trends in protein and peptidebased biomaterials for advanced drug delivery. Adv Drug Deliv Rev. (2020) 156:133-87. doi: 10.1016/j.addr.2020.08.008

44. Lanno G-M, Ramos C, Preem L, Putrinš M, Laidmäe I, Tenson $\mathrm{T}$, et al. Antibacterial porous electrospun fibers as skin scaffolds for wound healing applications. ACS Omega. (2020) 5:30011-22. doi: 10.1021/acsomega.0c04402

45. Jeckson TA, Neo YP, Sisinthy SP, Gorain B. Delivery of therapeutics from layer-by-layer electrospun nanofiber matrix for wound healing: an update. $J$ Pharm Sci. (2021) 110:635-53. doi: 10.1016/j.xphs.2020.10.003

46. Shoulders MD, Raines RT. Collagen structure and stability. Ann Rev Biochem. (2009) 78:92958. doi: 10.1146/annurev.biochem.77.032207.120833

47. Parenteau-Bareil R, Gauvin R, Cliche S, Gariépy C, Germain L, Berthod F. Comparative study of bovine, porcine and avian collagens for the production of a tissue engineered dermis. Acta Biomaterialia. (2011) 7:375765. doi: 10.1016/j.actbio.2011.06.020

48. Zhang J, Duan R. Characterisation of acid-soluble and pepsin-solubilised collagen from frog (Rana nigromaculata) skin. Int J Biol Macromol. (2017) 101:638-42. doi: 10.1016/j.ijbiomac.2017.03.143

49. Sotelo CG, Comesaña MB, Ariza PR, Pérez-Martín RI. Characterization of collagen from different discarded fish species of the west coast of the Iberian Peninsula. J Aquat Food Product Technol. (2016) 25:38899. doi: 10.1080/10498850.2013.865283

50. Khong NMH, Yusoff FM, Jamilah B, Basri M, Maznah I, Chan KW, et al. Improved collagen extraction from jellyfish (Acromitus hardenbergi) with increased physical-induced solubilization processes. Food Chem. (2018) 251:41-50. doi: 10.1016/j.foodchem.2017.12.083

51. Wang T, Lew J, Premkumar J, Poh CL, Win Naing M. Production of recombinant collagen: state of the art and challenges. Eng Biol. (2017) 1:18-23. doi: 10.1049/enb.2017.0003

52. Ennaas N, Hammami R, Gomaa A, Bédard F, Biron É, Subirade M, et al. Collagencin, an antibacterial peptide from fish collagen: activity, structure and interaction dynamics with membrane. Biochem Biophys Res Commun. (2016) 473:642-7. doi: 10.1016/j.bbrc.2016.03.121

53. Maeda M, Tani S, Sano A, Fujioka K. Microstructure and release characteristics of the minipellet, a collagen-based drug delivery system for controlled release of protein drugs. J Control Release. (1999) 62:313-24.

54. Bohn G, Liden B, Schultz G, Yang Q, Gibson DJ. Ovine-based collagen matrix dressing: next-generation collagen dressing for wound care. Adv Wound Care. (2016) 5:1-10. doi: 10.1089/wound.2015.0660

55. Fleck CA, Simman R. Modern collagen wound dressings: function and purpose. J Am College Certif Wound Spec. (2010) 2:50-4. doi: 10.1016/j.jcws.2010.12.003
56. Van Nieuwenhove I, Salamon A, Adam S, Dubruel P, Van Vlierberghe S, Peters K. Gelatin- and starch-based hydrogels. Part B: imesenchymal stem cell behavior on the hydrogels. Carbohydr Polym. (2017) 161:295305. doi: 10.1016/j.carbpol.2017.01.010

57. Singh O, Gupta SS, Soni M, Moses S, Shukla S, Mathur RK. Collagen dressing versus conventional dressings in burn and chronic wounds: a retrospective study. J Cutan Aesthet Surg. (2011) 4:12-6. doi: 10.4103/0974-2077.79180

58. Han G, Ceilley R. Chronic wound healing: a review of current management and treatments. Adv Therap. (2017) 34:599-610. doi: 10.1007/s12325-017-0478-y

59. Karnik T, Dempsey SG, Jerram MJ, Nagarajan A, Rajam R, May BCH, et al. Ionic silver functionalized ovine forestomach matrix - a non-cytotoxic antimicrobial biomaterial for tissue regeneration applications. Biomater Res. (2019) 23:6. doi: 10.1186/s40824-019-0155-0

60. Gopinath D, Kumar MS, Selvaraj D, Jayakumar R. Pexiganan-incorporated collagen matrices for infected wound-healing processes in rat. J Biomed Mater Res Part A. (2005) 73A:320-31. doi: 10.1002/jbm.a.30303

61. Shanmugasundaram N, Sundaraseelan J, Uma S, Selvaraj D, Babu M. Design and delivery of silver sulfadiazine from alginate microspheres-impregnated collagen scaffold. J Biomed Mater Res Part B Appl Biomater. (2006) 77B:37888. doi: 10.1002/jbm.b.30405

62. Adhirajan N, Shanmugasundaram N, Shanmuganathan S, Babu M. Collagen-based wound dressing for doxycycline delivery: in-vivo evaluation in an infected excisional wound model in rats. J Pharm Pharmacol. (2009) 61:1617-23. doi: 10.1211/jpp.61.12.0005

63. Cui F, Li G, Huang J, Zhang J, Lu M, Lu W, et al. Development of chitosan-collagen hydrogel incorporated with lysostaphin (CCHL) burn dressing with anti-methicillin-resistant Staphylococcus aureus and promotion wound healing properties. Drug Deliv. (2011) 18:173-80. doi: 10.3109/10717544.2010.509363

64. Albright V, Xu M, Palanisamy A, Cheng J, Stack M, Zhang B, et al. Micellecoated, hierarchically structured nanofibers with dual-release capability for accelerated wound healing and infection control. Adv Healthc Mater. (2018) 7:1800132. doi: 10.1002/adhm.201800132

65. Mebert AM, Alvarez GS, Peroni R, Illoul C, Hélary C, Coradin T, et al. Collagen-silica nanocomposites as dermal dressings preventing infection in vivo. Mater Sci Eng C. (2018) 93:170-7. doi: 10.1016/j.msec.2018.07.078

66. Shaik MM, Dapkekar A, Rajwade JM, Jadhav SH, Kowshik M. Antioxidantantibacterial containing bi-layer scaffolds as potential candidates for management of oxidative stress and infections in wound healing. J Mater Sci. (2019) 30:13. doi: 10.1007/s10856-018-6212-8

67. Balaure PC, Holban AM, Grumezescu AM, Mogoşanu GD, Bălşeanu TA, Stan MS, et al. In vitro and in vivo studies of novel fabricated bioactive dressings based on collagen and zinc oxide 3D scaffolds. Int J Pharm. (2019) 557:199-207. doi: 10.1016/j.ijpharm.2018.12.063

68. Lehman MK, Nuxoll AS, Yamada KJ, Kielian T, Carson SD, Fey PD. Protease-Mediated Growth of <span class="named-content genusspecies" id= "named-content-1" $>$ Staphylococcus aureus $</$ span $>$ on Host Proteins Is $<\mathrm{em}>\mathrm{opp} 3</ \mathrm{em}>$ dependent. mBio. (2019) 10:e0255318. doi: $10.1128 / \mathrm{mBio} .02553-18$

69. Nilebäck L, Chouhan D, Jansson R, Widhe M, Mandal BB, Hedhammar M. Silk-silk interactions between silkworm fibroin and recombinant spider silk fusion proteins enable the construction of bioactive materials. ACS Appl Mater Interfaces. (2017) 9:31634-44. doi: 10.1021/acsami. $7 \mathrm{~b} 10874$

70. Leal-Egaña A, Scheibel T. Silk-based materials for biomedical applications. Biotechnol Appl Biochem. (2010) 55:155-67. doi: 10.1042/BA20090229

71. Altman GH, Diaz F, Jakuba C, Calabro T, Horan RL, Chen J, et al. Silk-based biomaterials. Biomaterials. (2003) 24:40116. doi: 10.1016/s0142-9612(02)00353-8

72. Shao Z, Vollrath F. Surprising strength of silkworm silk. Nature. (2002) 418:741. doi: 10.1038/418741a

73. Farokhi M, Mottaghitalab F, Fatahi Y, Khademhosseini A, Kaplan DL. Overview of silk fibroin use in wound dressings. Trends Biotechnol. (2018) 36:907-22. doi: 10.1016/j.tibtech.2018.04.004

74. Seo YK, Yoon HH, Song KY, Kwon SY, Lee HS, Park YS, et al. Increase in cell migration and angiogenesis in a composite silk scaffold for tissue-engineered ligaments. J Orthop Res. (2009) 27:495-503. doi: 10.1002/jor.20752 
75. Horan RL, Antle K, Collette AL, Wang Y, Huang J, Moreau JE, et al. In vitro degradation of silk fibroin. Biomaterials. (2005) 26:338593. doi: 10.1016/j.biomaterials.2004.09.020

76. Numata K, Kaplan DL. Silk-based delivery systems of bioactive molecules. Adv Drug Deliv Rev. (2010) 62:1497-508. doi: 10.1016/j.addr.2010.03.009

77. Vepari C, Kaplan DL. Silk as a biomaterial. Prog Polym Sci. (2007) 32:9911007. doi: 10.1016/j.progpolymsci.2007.05.013

78. Lawrence BD, Cronin-Golomb M, Georgakoudi I, Kaplan DL, Omenetto FG. Bioactive silk protein biomaterial systems for optical devices. Biomacromolecules. (2008) 9:1214-20. doi: 10.1021/bm701235f

79. Calamak S, Erdogdu C, Ozalp M, Ulubayram K. Silk fibroin based antibacterial bionanotextiles as wound dressing materials. Mater Sci Eng C Mater Biol Appl. (2014) 43:11-20. doi: 10.1016/j.msec.2014.07.001

80. Pritchard EM, Valentin T, Panilaitis B, Omenetto F, Kaplan DL. Antibioticreleasing silk biomaterials for infection prevention and treatment. Adv Funct Mater. (2013) 23:854-61. doi: 10.1002/adfm.201201636

81. Yerra A, Mamatha DM. Antibiotic-based silk fibroin films for burn wound healing. Polym Adv Technol. (2021) 32:861-71. doi: 10.1002/pat.5137

82. Zhu G, Sun Z, Hui P, Chen W, Jiang X. Composite film with antibacterial gold nanoparticles and silk fibroin for treating multidrugresistant E. coli-infected wounds. ACS Biomater Sci Eng. (2020) 7:1827-35. doi: 10.1021/acsbiomaterials.0c01271

83. Yuan M, Dai F, Li D, Fan Y, Xiang W, Tao F, et al. Lysozyme/collagen multilayers layer-by-layer deposited nanofibers with enhanced biocompatibility and antibacterial activity. Mater Sci Eng C Mater Biol Appl. (2020) 112:110868. doi: 10.1016/j.msec.2020.110868

84. Shukla R, Cheryan M. Zein: the industrial protein from corn. Industr Crops Products. (2001) 13:171-92. doi: 10.1016/S0926-6690(00)00064-9

85. Dangaran K, Tomasula PM, Qi P. Structure and function of protein-based edible films and coatings. In: Huber KC, Embuscado ME, editors. Edible Films and Coatings for Food Applications. New York, NY: Springer New York (2009). p. 25-56. doi: 10.1007/978-0-387-92824-1_2

86. Momany FA, Sessa DJ, Lawton JW, Selling GW, Hamaker SAH, Willett JL. Structural characterization of $\alpha$-Zein. J Agricul Food Chem. (2006) 54:5437. doi: 10.1021/jf058135h

87. Corradini E, Curti PS, Meniqueti AB, Martins AF, Rubira AF, Muniz EC. Recent Advances in food-packing, pharmaceutical and biomedical applications of zein and zein-based materials. Int J Mol Sci. (2014) 15:2243870. doi: 10.3390/ijms151222438

88. Lai H-M, Padua GW. Properties and microstructure of plasticized zein films. Cereal Chem. (1997) 74:771-5. doi: 10.1094/CCHEM.1997.74.6.771

89. Paliwal R, Palakurthi S. Zein in controlled drug delivery and tissue engineering. J Controlled Release. (2014) 189:10822. doi: 10.1016/j.jconrel.2014.06.036

90. Unnithan AR, Gnanasekaran G, Sathishkumar Y, Lee YS, Kim CS. Electrospun antibacterial polyurethane-cellulose acetate-zein composite mats for wound dressing. Carbohydr Polym. (2014) 102:884-92. doi: 10.1016/j.carbpol.2013.10.070

91. Dashdorj U, Reyes MK, Unnithan AR, Tiwari AP, Tumurbaatar B, Park CH, et al. Fabrication and characterization of electrospun zein/Ag nanocomposite mats for wound dressing applications. Int J Biol Macromol. (2015) 80:17. doi: 10.1016/j.ijbiomac.2015.06.026

92. Alhusein N, Blagbrough IS, Beeton ML, Bolhuis A, De Bank PA. Electrospun Zein/PCL fibrous matrices release tetracycline in a controlled manner, killing Staphylococcus aureus both in biofilms and ex vivo on pig skin, and are compatible with human skin cells. Pharm Res. (2016) 33:23746. doi: 10.1007/s11095-015-1782-3

93. Pedram Rad Z, Mokhtari J, Abbasi M. Fabrication and characterization of $\mathrm{PCL} /$ zein/gum arabic electrospun nanocomposite scaffold for skin tissue engineering. Mater Sci Eng C. (2018) 93:356-66. doi: 10.1016/j.msec.2018.08.010

94. Kimna C, Tamburaci S, Tihminlioglu F. Novel zein-based multilayer wound dressing membranes with controlled release of gentamicin. J Biomed Mater Res Part B Appl Biomater. (2019) 107:2057-70. doi: 10.1002/jbm.b. 34298

95. Kratz F. Albumin as a drug carrier: design of prodrugs, drug conjugates and nanoparticles. J Control Release. (2008) 132:171-83. doi: 10.1016/j.jconrel.2008.05.010
96. Kratz F. A clinical update of using albumin as a drug vehicle - a commentary. J Control Release. (2014) 190:331-6. doi: 10.1016/j.jconrel.2014.03.013

97. Maiti D, Chao Y, Dong Z, Yi X, He J, Liu Z, et al. Development of a thermosensitive protein conjugated nanogel for enhanced radio-chemotherapy of cancer. Nanoscale. (2018) 10:1397685. doi: 10.1039/C8NR03986K

98. Ribeiro M, Monteiro FJ, Ferraz MP. Infection of orthopedic implants with emphasis on bacterial adhesion process and techniques used in studying bacterial-material interactions. Biomatter. (2012) 2:17694. doi: 10.4161/biom.22905

99. Ruiz V, Rodríguez-Cerrato V, Huelves L, Del Prado G, Naves P, Ponte C, et al. Adherence of Streptococcus pneumoniae to polystyrene plates and epithelial cells and the antiadhesive potential of albumin and xylitol. Pediatr Res. (2011) 69:23-7. doi: 10.1203/PDR.0b013e3181fed2b0

100. Naves P, del Prado G, Huelves L, Rodríguez-Cerrato V, Ruiz V, Ponte MC, et al. Effects of human serum albumin, ibuprofen and $\mathrm{N}$-acetyl-L-cysteine against biofilm formation by pathogenic Escherichia coli strains. J Hosp Infect. (2010) 76:165-70. doi: 10.1016/j.jhin.2010.05.01

101. del Prado G, Ruiz V, Naves P, Rodríguez-Cerrato V, Soriano F, del Carmen Ponte M. Biofilm formation by Streptococcus pneumoniae strains and effects of human serum albumin, ibuprofen, N-acetyl-l-cysteine, amoxicillin, erythromycin, and levofloxacin. Diagn Microbiol Infect Dis. (2010) 67:3118. doi: 10.1016/j.diagmicrobio.2010.03.016

102. Brokke P, Dankert J, Carballo J, Feijen J. Adherence of coagulase-negative staphylococci onto polyethylene catheters in vitro and in vivo: a study on the influence of various plasma proteins. Journal of Biomaterials Applications. (1991) 5:204-26. doi: 10.1177/088532829100500305

103. Patzelt A, Mak WC, Jung S, Knorr F, Meinke MC, Richter H, et al. Do nanoparticles have a future in dermal drug delivery? J Controlled Release. (2017) 246:174-82. doi: 10.1016/j.jconrel.2016.09.015

104. Purdie L, Alexander C, Spain SG, Magnusson JP. Alkylmodified oligonucleotides as intercalating vehicles for doxorubicin uptake via albumin binding. Mol Pharm. (2018) 15:43746. doi: 10.1021/acs.molpharmaceut.7b00805

105. Davoodi SH, Shahbazi R, Esmaeili S, Sohrabvandi S, Mortazavian A, Jazayeri S, et al. Health-related aspects of milk proteins. Iran J Pharm Res. (2016) 15:573-91. doi: 10.22037/IJPR.2016.1897

106. Elzoghby AO, Abo El-Fotoh WS, Elgindy NA. Casein-based formulations as promising controlled release drug delivery systems. J Controlled Release. (2011) 153:206-16. doi: 10.1016/j.jconrel.2011.02.010

107. Pojanavaraphan T, Magaraphan R, Chiou B-S, Schiraldi DA. Development of biodegradable foamlike materials based on casein and sodium montmorillonite clay. Biomacromolecules. (2010) 11:2640-6. doi: 10.1021/bm100615a

108. Penalva R, Esparza I, Agüeros M, Gonzalez-Navarro CJ, Gonzalez-Ferrero C, Irache JM. Casein nanoparticles as carriers for the oral delivery of folic acid. Food Hydrocolloids. (2015) 44:399-406. doi: 10.1016/j.foodhyd.2014.10.004

109. Willmott N, Magee GA, Cummings J, Halbert GW, Smyth JF. Doxorubicinloaded casein microspheres: protean nature of drug incorporation. J Pharm Pharmacol. (1992) 44:472-5. doi: 10.1111/j.2042-7158.1992.tb03649.x

110. Picchio ML, Cuggino JC, Nagel G, Wedepohl S, Minari RJ, Alvarez Igarzabal $\mathrm{CI}$, et al. Crosslinked casein-based micelles as a dually responsive drug delivery system. Polym Chem. (2018) 9:3499-510. doi: 10.1039/C8PY00600H

111. Picchio ML, Paredes AJ, Palma SD, Passeggi MCG, Gugliotta LM, Minari RJ, et al. pH-responsive casein-based films and their application as functional coatings in solid dosage formulations. Colloids Surf A. (2018) 541:19. doi: 10.1016/j.colsurfa.2018.01.012

112. Song F, Zhang L-M, Yang C, Yan L. Genipin-crosslinked casein hydrogels for controlled drug delivery. Int J Pharm. (2009) 373:41-7. doi: 10.1016/j.ijpharm.2009.02.005

113. Selvaraj S, Thangam R, Fathima NN. Electrospinning of casein nanofibers with silver nanoparticles for potential biomedical applications. Int J Biol Macromol. (2018) 120:1674-81. doi: 10.1016/j.ijbiomac.2018.09.177

114. Biranje S, Madiwale P, Adivarekar RV. Porous electrospun Casein/PVA nanofibrous mat for its potential application as wound dressing material. $J$ Porous Mater. (2019) 26:29-40. doi: 10.1007/s10934-018-0602-7

115. Hoffman AS. Hydrogels for biomedical applications. Adv Drug Deliv Rev. (2002) 54:3-12. doi: 10.1016/S0169-409X(01)00239-3 
116. Peppas NA, Bures P, Leobandung W, Ichikawa $\mathrm{H}$. Hydrogels in pharmaceutical formulations. Eur $J$ Pharm Biopharm. (2000) 50:27-46. doi: 10.1016/S0939-6411(00)00 090-4

117. Chai Q, Jiao Y, Yu X. Hydrogels for biomedical applications: their characteristics and the mechanisms behind them. Gels. (2017) 3:6. doi: $10.3390 /$ gels3010006

118. Panahi R, Baghban-Salehi M. Protein-based hydrogels. In: Mondal MIH, editor. Cellulose-Based Superabsorbent Hydrogels. Cham: Springer International Publishing (2019). p. 1561600. doi: 10.1007/978-3-319-77830-3_52

119. Hu W, Wang Z, Xiao Y, Zhang S, Wang J. Advances in crosslinking strategies of biomedical hydrogels. Biomater Sci. (2019) 7:843-55. doi: 10.1039/C8BM01246F

120. Dinescu S, Albu Kaya M, Chitoiu L, Ignat S, Kaya DA, Costache M. Collagen-based hydrogels and their applications for tissue engineering and regenerative medicine. In: Mondal MIH, editor. Cellulose-Based Superabsorbent Hydrogels. Cham: Springer International Publishing (2019). p. 1643-64. doi: 10.1007/978-3-319-77830-3_54

121. Zhu S, Yuan Q, Yin T, You J, Gu Z, Xiong S, et al. Self-assembly of collagen-based biomaterials: preparation, characterizations and biomedical applications. J Mater Chem B. (2018) 6:2650-76. doi: 10.1039/C7TB02999C

122. Kim U-J, Park J, Li C, Jin H-J, Valluzzi R, Kaplan DL. Structure and properties of silk hydrogels. Biomacromolecules. (2004) 5:78692. doi: $10.1021 / \mathrm{bm} 0345460$

123. Borkner CB, Elsner MB, Scheibel T. Coatings and films made of silk proteins. ACS Appl Mater Interf. (2014) 6:15611-25. doi: 10.1021/am5008479

124. Hu X, Cebe P, Weiss AS, Omenetto F, Kaplan DL. Proteinbased composite materials. Mater Today. (2012) 15:20815. doi: 10.1016/S1369-7021(12)70091-3

125. Wang L-S, Gopalakrishnan S, Lee Y-W, Zhu J, Nonnenmann SS, Rotello VM. Translation of protein charge and hydrophilicity to materials surface properties using thermal treatment in fluorous media. Mater Horiz. (2018) 5:268-74. doi: 10.1039/C7MH00933J

126. Zhang L, Gopalakrishnan S, Li K, Wang L-S, Han Y, Rotello VM. Fabrication of collagen films with enhanced mechanical and enzymatic stability through thermal treatment in fluorous media. ACS Appl Mater Interf. (2020) 12:65907. doi: 10.1021 /acsami.9b18256

127. Pang H, Zhao S, Mo L, Wang Z, Zhang W, Huang A, et al. Mussel-inspired bio-based water-resistant soy adhesives with low-cost dopamine analogue-modified silkworm silk fiber. J Appl Polym Sci. (2020) 137:48785. doi: 10.1002/app.48785

128. Bax DV, Smalley HE, Farndale RW, Best SM, Cameron RE. Cellular response to collagen-elastin composite materials. Acta Biomater. (2019) 86:15870. doi: 10.1016/j.actbio.2018.12.033

129. Jiang C, Wang X, Gunawidjaja R, Lin YH, Gupta MK, Kaplan DL, et al. Mechanical properties of robust ultrathin silk fibroin films. Adv Funct Mater. (2007) 17:2229-37. doi: 10.1002/adfm.200601136

130. You R, Zhang J, Gu S, Zhou Y, Li X, Ye D, et al. Regenerated egg white/silk fibroin composite films for biomedical applications. Mater Sci Eng C. (2017) 79:430-5. doi: 10.1016/j.msec.2017.05.063

131. Kim HJ, Kim HS, Matsumoto A, Chin I-J, Jin H-J, Kaplan DL. Processing windows for forming silk fibroin biomaterials into a 3D porous matrix. Aust J Chem. (2005) 58:716-20. doi: 10.1071/CH05170

132. Lu Q, Hu X, Wang X, Kluge JA, Lu S, Cebe P, et al. Waterinsoluble silk films with silk I structure. Acta Biomater. (2010) 6:13807. doi: 10.1016/j.actbio.2009.10.041

133. Xu J, Liu F, Goff HD, Zhong F. Effect of pre-treatment temperatures on the film-forming properties of collagen fiber dispersions. Food Hydrocolloids. (2020) 107:105326. doi: 10.1016/j.foodhyd.2019.105326

134. McManamon C, Cameron A, de Silva JP, Daly R, O’Brien FJ, Cross GLW. Effect of cross-linking and hydration on microscale flat punch indentation contact to collagen-hyaluronic acid films in the viscoelastic limit. Acta Biomater. (2020) 111:279-89. doi: 10.1016/j.actbio.2020.04.043

135. Xu J, Liu F, Wang T, Goff HD, Zhong F. Fabrication of films with tailored properties by regulating the swelling of collagen fiber through $\mathrm{pH}$ adjustment. Food Hydrocolloids. (2020) 108:106016. doi: 10.1016/j.foodhyd.2020.106016
136. Boateng JS, Auffret AD, Matthews KH, Humphrey MJ, Stevens HNE, Eccleston GM. Characterisation of freeze-dried wafers and solvent evaporated films as potential drug delivery systems to mucosal surfaces. Int $J$ Pharm. (2010) 389:24-31. doi: 10.1016/j.ijpharm.2010.01.008

137. Pereira HA. Novel therapies based on cationic antimicrobial peptides. Curr Pharm Biotechnol. (2006) 7:229-34. doi: 10.2174/138920106777950771

138. Shukla A, Fleming KE, Chuang HF, Chau TM, Loose CR, Stephanopoulos GN, et al. Controlling the release of peptide antimicrobial agents from surfaces. Biomaterials. (2010) 31:234857. doi: 10.1016/j.biomaterials.2009.11.082

139. Ki CS, Park SY, Kim HJ, Jung H-M, Woo KM, Lee JW, et al. Development of 3-D nanofibrous fibroin scaffold with high porosity by electrospinning: implications for bone regeneration. Biotechnol Lett. (2008) 30:405-10. doi: 10.1007/s10529-007-9581-5

140. Garg K, Bowlin GL. Electrospinning jets and nanofibrous structures. Biomicrofluidics. (2011) 5:13403. doi: 10.1063/1.3567097

141. Niu $\mathrm{H}$, Zhou $\mathrm{H}$, Wang $\mathrm{H}$. Electrospinning: an advanced nanofiber production technology. In: Fang J, Lin T, editors. Energy Harvesting Properties of Electrospun Nanofibers. IOP Publishing (2019). p. 1-44.

142. Pant B, Park M, Park S-J. Drug delivery applications of core-sheath nanofibers prepared by coaxial electrospinning: a review. Pharmaceutics. (2019) 11:305. doi: 10.3390/pharmaceutics11070305

143. Miyoshi T, Toyohara K, Minematsu H. Preparation of ultrafine fibrous zein membranes via electrospinning. Polymer Int. (2005) 54:118790. doi: $10.1002 /$ pi. 1829

144. Wang Y, Padua GW. Nanoscale characterization of zein self-assembly. Langmuir. (2012) 28:2429-35. doi: 10.1021/la204204j

145. Li Y, Xia Q, Shi K, Huang Q. Scaling behaviors of $\alpha$-zein in acetic acid solutions. J Phys Chem B. (2011) 115:9695-702. doi: 10.1021/jp203476m

146. Kanjanapongkul $\mathrm{K}$, Wongsasulak $\mathrm{S}$, Yoovidhya $\mathrm{T}$. Investigation and prevention of clogging during electrospinning of zein solution. J Appl Polym Sci. (2010) 118:1821-9. doi: 10.1002/app.32499

147. Vogt L, Liverani L, Roether JA, Boccaccini AR. Electrospun zein fibers incorporating poly(glycerol sebacate) for soft tissue engineering. Nanomaterials. (2018) 8:150. doi: 10.3390/nano8030150

148. Akhmetova A, Lanno G-M, Kogermann K, Malmsten M, Rades T, Heinz A. Highly elastic and water stable zein microfibers as a potential drug delivery system for wound healing. Pharmaceutics. (2020) 12:458. doi: 10.3390/pharmaceutics12050458

149. Zhang J-F, Wang Y, Liao S, Lallier T, Wen ZT, Xu X. Photo-cross-linked antibacterial zein nanofibers fabricated by reactive electrospinning and its effects against Streptococcus mutans. Oral Health Dent Stud. (2017) 1:1. doi: 10.31532/OralHealthDentStud.1.1.001

150. Horne DS. Casein structure, self-assembly and gelation. Curr Opin Colloid Interface Sci. (2002) 7:456-61. doi: 10.1016/S1359-0294(02)00082-1

151. Tomasula PM, Sousa AMM, Liou SC, Li R, Bonnaillie LM, Liu LS. Short communication: Electrospinning of casein/pullulan blends for food-grade applications. J Dairy Sci. (2016) 99:1837-45. doi: 10.3168/jds.2015-10374

152. Farè S, Torricelli P, Giavaresi G, Bertoldi S, Alessandrino A, Villa $\mathrm{T}$, et al. In vitro study on silk fibroin textile structure for anterior cruciate ligament regeneration. Mater Sci Eng C. (2013) 33:36018. doi: 10.1016/j.msec.2013.04.027

153. Johari N, Moroni L, Samadikuchaksaraei A. Tuning the conformation and mechanical properties of silk fibroin hydrogels. Eur Polymer J. (2020) 134:109842. doi: 10.1016/j.eurpolymj.2020.109842

154. Miele D, Catenacci L, Rossi S, Sandri G, Sorrenti M, Terzi A, et al. Collagen/PCL nanofibers electrospun in green solvent by DOE assisted process. An insight into collagen contribution. Materials. (2020) 13:4698. doi: 10.3390/ma13214698

155. Law JX, Liau LL, Saim A, Yang Y, Idrus R. Electrospun collagen nanofibers and their applications in skin tissue engineering. Tissue Eng Regen Med. (2017) 14:699-718. doi: 10.1007/s13770-017-0075-9

156. Datta LP, Manchineella S, Govindaraju T. Biomolecules$\begin{array}{llll}\text { derived biomaterials. Biomaterials. (2020) 230:119633. } & \text { (20) }\end{array}$ doi: 10.1016/j.biomaterials.2019.119633

157. Ghorbani M, Mahmoodzadeh F, Yavari Maroufi L, NezhadMokhtari P. Electrospun tetracycline hydrochloride loaded zein/gum tragacanth/poly lactic acid nanofibers for biomedical application. Int $J$ 
Biol Macromol. (2020) 165(Pt A):1312-22. doi: 10.1016/j.ijbiomac.2020. 09.225

158. Xue M, Jackson CJ. Extracellular matrix reorganization during wound healing and its impact on abnormal scarring. Adv Wound Care. (2015) 4:119-36. doi: 10.1089/wound.20 13.0485

159. Lin T, Lu C, Zhu L, Lu T. The biodegradation of zein in vitro and in vivo and its application in implants. AAPS PharmSciTech. (2011) 12:1726. doi: 10.1208/s12249-010-9565-y

160. Chattopadhyay S, Raines RT. Review collagen-based biomaterials for wound healing. Biopolymers. (2014) 101:821-33. doi: 10.1002/bip.22486

161. Maciel KS, Santos LS, Bonomo RCF, Verissimo LAA, Minim VPR, Minim LA. Purification of lactoferrin from sweet whey using ultrafiltration followed by expanded bed chromatography. Separat Purif Technol. (2020) 251:117324. doi: 10.1016/j.seppur.2020.117324

162. Verderosa AD, Totsika M, Fairfull-Smith KE. Bacterial biofilm eradication agents: a current review. Front Chem. (2019) 7:824. doi: $10.3389 /$ fchem. 2019.00824

163. Roy R, Tiwari M, Donelli G, Tiwari V. Strategies for combating bacterial biofilms: a focus on anti-biofilm agents and their mechanisms of action. Virulence. (2018) 9:522-54. doi: 10.1080/21505594.2017.1313372

164. Ashtikar M, Wacker MG. Nanopharmaceuticals for wound healing - Lost in translation? Adv Drug Deliv Rev. (2018) 129:194-218. doi: 10.1016/j.addr.2018.03.005

165. Pace CN, Treviño S, Prabhakaran E, Scholtz JM. Protein structure, stability and solubility in water and other solvents. Philos Trans $R$ Soc Lond B Biol Sci. (2004) 359:1225-35. doi: 10.1098/rstb.2004. 1500

166. Dai Z, Ronholm J, Tian Y, Sethi B, Cao X. Sterilization techniques for biodegradable scaffolds in tissue engineering applications. $J$ Tissue Eng. (2016) 7:2041731416648810. doi: 10.1177/2041731416 648810

167. Gauza-Włodarczyk M, Kubisz L, Włodarczyk D. Amino acid composition in determination of collagen origin and assessment of physical factors effects. Int J Biol Macromol. (2017) 104:987-91. doi: 10.1016/j.ijbiomac.2017. 07.013
168. Rnjak-Kovacina J, DesRochers TM, Burke KA, Kaplan DL. The effect of sterilization on silk fibroin biomaterial properties. Macromol Biosci. (2015) 15:861-74. doi: 10.1002/mabi.201500013

169. Rabotyagova OS, Cebe P, Kaplan DL. Collagen structural hierarchy and susceptibility to degradation by ultraviolet radiation. Mater Sci Eng C. (2008) 28:1420-9. doi: 10.1016/j.msec.2008.03.012

170. Herdegen V, Felix A, Haseneder R, Repke J-U, Leppchen-Fröhlich $\mathrm{K}$, Prade I, et al. Sterilization of medical products from collagen by means of supercritical CO2. Chem Eng Technol. (2014) 37:18915. doi: 10.1002/ceat.201300679

171. Delgado LM, Pandit A, Zeugolis DI. Influence of sterilisation methods on collagen-based devices stability and properties. Expert Rev Med Dev. (2014) 11:305-14. doi: 10.1586/17434440.2014.900436

172. Meyer M. Processing of collagen based biomaterials and the resulting materials properties. BioMed Eng OnLine. (2019) 18:24. doi: 10.1186/s12938-019-0647-0

173. Ni N, Dumont M-J. Protein-based hydrogels derived from industrial byproducts containing collagen, keratin, zein and soy. Waste Biomass Valoriz. (2017) 8:285-300. doi: 10.1007/s12649-016-9684-0

174. Tiwari SK, Venkatraman S. Electrospinning pure protein solutions in coreshell fibers. Polym Int. (2012) 61:1549-55. doi: 10.1002/pi.4246

175. Jin H-J, Fridrikh SV, Rutledge GC, Kaplan DL. Electrospinning Bombyx mori silk with poly(ethylene oxide). Biomacromolecules. (2002) 3:12339. doi: $10.1021 / \mathrm{bm} 025581 \mathrm{u}$

Conflict of Interest: The authors declare that the research was conducted in the absence of any commercial or financial relationships that could be construed as a potential conflict of interest.

Copyright (c) 2021 Thapa, Grønlien and Tønnesen. This is an open-access article distributed under the terms of the Creative Commons Attribution License (CC BY). The use, distribution or reproduction in other forums is permitted, provided the original author(s) and the copyright owner(s) are credited and that the original publication in this journal is cited, in accordance with accepted academic practice. No use, distribution or reproduction is permitted which does not comply with these terms. 